\title{
Substantiation of conditions of formation in junior preschoolers' positive attitude towards the preschool institution at the stage of adaptation
}

\author{
N. Gavrysh, N. Shklyar \\ Laboratory of pre-school education and training, at the Institute of Educational Problems \\ of the National Academy of Pedagogical Sciences of Ukraine, Kiev \\ Corresponding author. E-mail: n.rodinaga@ukr.net, natasha_shklyar@bigmir.net
}

Paper received 30.08.18; Accepted for publication 05.09.18.

https://doi.org/10.31174/SEND-PP2018-175VI73-13 Abstract. The article deals with the significance of a close relationship between family and institution of preschool education in order to
create for each child a single educational environment aimed at the development of the child's personality. The author claims that the
patterns of children's future life are formed under the influence of parents and other close relatives.

Keywords: adaptation, preschooler, institution of preschool education, family education, socialization.

Problem statement. In the last few years there has been a growing interest in socialization of personality at the early stages of ontogenesis. This is due to socio-cultural changes in personal development, the contradictory state of sociopedagogical theory and practice. The current situation of instability has led to a transformation of social life, changes in the forms of social control and role of social institutions, as well as socialization itself.

According to scientists, person's system of values and basic qualities are manifested through one's attitude towards oneself, the immediate environment and society as a whole. Moreover, they are reflected through personal interrelations between nature, society and art, as well as adoption of national and family traditions, relationships with peers, children and adults [6]. Valuable attitude towards both society and state begins with the child's awareness of oneself as a member of family, human race, children's community, a sense of love for his or her home, street, native word, everyday life, traditions.

The axiological foundations of humanistic pedagogy are based on the principles presented in the Laws of Ukraine "On Education", "On General Secondary Education", "On Preschool Education", "On Out-of-School Education" and other legislative documents. These documents have established the priority of a developed personality, life selfdetermination, self-realization in accordance with her or his interests and social requirements [6].

Analysis of recent researches and publications. Preschool childhood has become a central issue in modern studies (L. Artemova, A. Bohush, Z. Borysova, N. Havrysh, I. Kindrat, O. Kononko, S. Ladyvir, V. Orzhekhovska, Z. Plokhii, T. Ponimanska, V. Postovyi, etc.). The past decade has seen a renewed importance in content of education of children in order to determine the optimal conditions for the functioning of educational institutions of various types, psychological and pedagogical conditions for effective development of children in family and institutions of preschool education. Recent scientific researches have focused on educational potential of family and institution of preschool education as the main institutes of socialization at early stages of ontogenesis (O. Bohinich, V. Kotyrlo, T. Naumenko, O. Nikitin, B. Nikitin, M. Osorina, L. Ostrovska, T. Ponimanska, O. Khartman).

Previous psychological studies have considered the problem of personal development during childhood in different aspects:

- $\quad$ personal development in ontogenesis and features of structuring of its components (O. Kononko,
V. Kudriavtsev, O. Leontiev, A. Petrovskyi, T. Pirozhenko, D. Feldshtein);

- formation of self-consciousness, basic self-image as a condition for formation of subjectivity, which is a manifestation of personal activity at various stages of ontogenesis (B. Ananiev, M. Yelagina, V. Zenkovskyi, Ye. Isaev, V. Mukhina, S. Novoselov, V. Slobodchykov, R. Strvorkina);

- $\quad$ specifics of formation of a preschoolers' positive attitude towards the world and themselves, the nature of its manifestations, orientation and degrees of development (N. Aksarina, T. Bauer, L. Bozhovyich, A. Vallon, L. Venger, Z. Gurina, D. Elkonin, O. Zaporozhets, V. Kotyrlo, V. Kuzmenko, S. Ladyvir, Ya. Neverovych, O. Proskura);

- role of family and institution of preschool education in order to personal development at early ontogenesis (N. Avdeeva, O. Kononko, G. Lublinska, S. Meshcheriakova, T. Naumenko).

The aim of this study is devoted to the problem of establishing relationships between family and family education. Each of these branches is a social institution of education, has its own specific capabilities for child's development. Many hypotheses regarding these two branches appear to be debatable. J. Comenius gave the mother school a priority, and the mother's lessons had to be without changes in the schedule, weekends and holidays. The pedagogue-humanist J. Pestalozzi defined family as a proper tool of education. Family's example teaches children and the living word complements it. Therefore, it has a particular impact. According to another approach, family is one of the obstacles for formation of a new individual ( $R$. Owen). He supported the idea that social education of a child plays an exclusive role. His idea was actively implemented in our country. On the other hand, families become a "cell" with "backward" traditions and customs. Over the years, it has been highlighted the leading role of public education for personal development of child.

Our research is based on the approach proposed by T. Alekseenko, A. Bohush, N. Havrysh, O. Kononko, V. Kuzmenko, S. Kulachkivska, S. Kurinna, G. Lublinska, I. Rohalska, T. Pirozhenko, T. Ponimanska, etc.). According this approach, there is a strong relationship between two first social institutions - family and institution of preschool education. Both preschool institution and family are a source of socializing influence on children that purposefully develop the children's behavior patterns, their values, and a system of relations with the environment. 
A number of studies have found that family has socializing influence on formation of microsocial and sociocultural impacts, religious traditions, ethnic and sex-role stereotypes, moral abilities of children. Several studies are devoted to the styles of family education (O. Belinska,

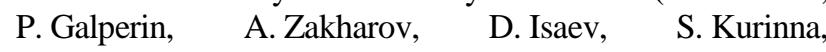
I. Makarenko, V. Merlin, J. Piaget, I. Pechenko, M. Rosenberg, S. Rubinstein, V. Semichenko, E. Sokolova, I. Chesnokova O. Tikhomandritska, etc.). Scientists have revealed that requirements for education and development of child's consciousness should be equal. Furthermore, communication between parents and teachers for children well-being ought to be at the stage of children's transition to new social institutions.

Main results. We consider the problem of children's adaptation to a new social situation in the context of socialization. We define socialization as a person's acceptance of certain group norms, beliefs, values and norms of higher or lower status which are typical for groups. Literature review has shown that scientists the primary socialization of personality in a stratified society has identified as an important direction of socialization, but it is not well-grounded (A. Kovaleva, M. Lukashevych, R. Merton, A. Mudryk, T. Parsons, A. Tashchenko).

In this paper we use the term of person's primary socialization provided by I. Kon. He defines it as "a combination of social processes through which the person assimilates and reproduces a certain system of knowledge, norms and values that allow personality to become a full member of a society" [4]. In spite of the diversity of definitions, interaction between human and social world is common. And as a result of such interaction, personality will develop. G. Andreeva identifies socialization as a two-way process that includes a two-way process of social experience acquisition, integration into social environment, a system of social relations due to person's intensive activity. This point of view determines two phases in the process of socialization: social adaptation and integration. The process of adaptation is very difficult, and different people move through it in different ways. Eventually, each person adapts to one's own social environment [1].

The adaptation of younger generation, influence on this process by family as the institution of children's primary socialization have been widely investigated According to N. Vatutina, L. Galiguzova, O. Zaporozhets, O. Kononko, M. Lisina, T. Naumenko, Zh. Yusvak, the essence and peculiarities of the process of adaptation depend on the role and place of family during this period children's life, In addition, adaptation is closely linked to the previous conditions for its development and education. Based on theoretical analysis of this issue and study of practice of institutions of preschool educational, such researchers as N. Vatutina, T. Zharovtseva and Zh. Yuzvak offered a system of measures of psychological and pedagogical influence of family on preparation of children of early and junior preschool age for visiting institution of preschool education.

The process of child's social development starts at early childhood and occurs in a certain social environment. The child develops within the limits of his or her family, social and national environment. Media, socio-cultural environment, events, which happen in children's close environment, have a significant influence on their socialization. The social environment is a complex structural entity characterized by interconnected relations between the constituents. According to R. Pavelkov, the social environment is the unity of the following components:

- macro-environment (society as a certain sociopolitical, socio-economic and ideological system);

- meso-environment (national-cultural, social features of the region);

- micro-environment (direct environment of the child's life: family, neighbors, groups of peers, cultural and educational institutions).

These components of the social environment have a significant impact on preschoolers' socialization at different periods of their childhood [7].

The main purpose of family is to form the first social needs of children - the necessity for social contact (M. Lisina), basic trust in the world (E. Erikson), commitment (J. Bowlby \& M. Ainsworth) in childhood. Moreover, formation of subject and manipulation competences at early age and social competence at preschool age is important, as well as cooperation and support in self-education at the primary school age.

Family has a socio-cultural nature. It is characterized by a system of social norms and rules that regulate the distribution of functions between parents for caring and education of their children. Parents are responsible to society for a system of conditions that correspond to the age-specific features of their child at each stages of ontogenesis, the optimal opportunities that ensure child's personal and mental development as well [3].

The term "family education" is used to refer to the interaction between parents and children based on the family's emotional intimacy, love, care, respect and protection of the child\$ it promotes creation of favorable conditions for satisfying children's needs for their full development and selfdevelopment.

Currently, few adults have a high level of pedagogical knowledge: how to communicate with preschoolers, how to develop and educate them. That is why there is a necessity to help parents in their child's education. The efficiency of this work will be ensured by interaction between institution of preschool education and family. Features of interaction with parents of children of early age and preschool age have been carried out by N. Avdeeva, N. Aksarina, O. Volkova, G. Markova, \& O. Matveeva. The review of literature on theoretical and methodological aspects of this problem (T. Golubeva, L. Ostrovskaya, V. Pavlenschik) has indicated that there are a number of important changes not only in content of interaction with parents, but only in the requirements for educators, their role and place in social transformations (I. Desnova).

The institution of preschool education is the first out of family social institution, the first educational institution contacts with parents and provides their systematic pedagogical education. The further development of child depends on the joint work between parents and teachers. In addition, the quality of work of institution of preschool education, namely, psychological and pedagogical education, depends on the level of parents' pedagogical culture. Consequently, it influences on the level of children's family education. T. Dronova defines psychological and pedagogical education of parents as a systematic interaction between educators of institution of preschool education and parents in order to transfer knowledge and practical skills in various fields of family education. 
Nowadays, majority of institutions of preschool education perceive educational work and cooperation with parents as one of the most important aim. Both administration and teachers explain to parents their exclusive role in child's development, the importance of targeted developmental work at home and its unity with the educational process in institution of preschool education. However, these efforts do not always give the expected results that depend on a system of family values and level of personal culture of each parent. To avoid family misunderstanding, to preserve the health of parents and their children, families need pedagogical and psychological support. Successful educational work is impossible without a system of pedagogical education, promotion of parents' pedagogical culture, which is an integral part of a general culture.

The institution of preschool education faces the problem of how to improve the existing approaches and find new modern approaches to organize work with children's families. The quality of this work depends on the level of pedagogical culture of parents which affects the adults' willingness and ability to appropriately organize the educational process.

The problem of child's adaptation to preschool education can be solved through targeted work with parents and specially organized work with children. Scientists of all times and scientific schools focus on early socialization (integration into society, gaining social experience, mastering social roles) in institution of preschool education, which are specific "children's reserves". From three or four years, children show their keen interest in the environment as a means of organizing their own lives, attempts to conquer it for their own interests [8].

O. Kononko draws the same conclusions and pays special attention to family relations as well as the general emotional atmosphere for children in their families. In addition, she highlights the crucial role of the social environment, which acts as a decisive factor in child's development. O. Kononko has used Zhd. G. Mid's theory about three stages of socialization. The first stage is imitation: children copy adults' behavior without clear understanding it. Therefore, this stage is extremely responsible for creation the worthy environment of imitation. The second stage is role-play games: experimenting in adults' roles through games, children "try on" them to themselves, learn to give their thoughts and actions the same meaning as adults, that is, intuitively assimilate certain social norms. The final, third stage, is collective games: children learn to take into account the existence in the world not only themselves, but other people, learn to focus on their expectations as well.
Transparency of institution of preschool education promote the children's proper level of knowledge about social world, development and acquisition the diversity of its social relations based on active, consistent and subjective perception. The main result of its functioning is successful interaction with the society. As a result, institution of preschool education will become an important social institution of children's socialization.

When children visit kindergarten, they are often unprepared for new conditions and rules of collaboration. The experience how to join the team, establish contacts, play common games with peers, understand the basic rules of rational life, organized activities are all important elements of competence, which is an integrated characteristic of a preschoolers as a personality. All this affects both the children's individual experience and their attitudes, expectations, plans. The environment cannot offer child the perfect model of organization of life, so the child must rely on his or her individual experience, the ability to vary, adapt, avoid, resist. Therefore, children master a complicated art how to enter into life and be a competent person.

The results of this research support the idea that institution of preschool education is the most effective form of preschool education. Children's life competence and primary social experience are developed prolonged, gradually in institution of preschool education. This paper has clearly shown that institutions of preschool education provide the system approach in order to fully children's development, education and training. Children, who attend institution of preschool education before going to school, are in a more favorable condition. Except the experience of family socialization, these children also have a social experience gained in the process of a variety of life practices of communication and interaction with peers, and teachers. Therefore, in the context of our study, we consider socialization as a preschoolers' positive attitude towards institution of preschool education and the successful adaptation of child to a new social situation [9].

Conclusions. From the research that has been carried out, it is possible to conclude that interaction between family and social education is one of the main factors for effective process in order to develop junior preschoolers' primary social experience. Successful socialization of preschoolers is a common mission for institution of preschool education and family. Full implementation of this aim will require the coherence of adults. Both teachers and family members must realize that they and children are equal participants in the pedagogical process, as well as they must interact on the principles of trust, partnership, mutual respect, unity of requirements.

\section{REFERENCES}

1. Andreeva, G. M. (2001). Sotsialnaia psikhologiia [Social psychology]. Moscow: Aspekt Press.

2. Zakharova, N. M. (2010). Adaptatsiia ditei doshkilnoho viku do suchasnoho sotsialnoho prostoru [Adaptation of children of preschool age to modern social space]. Donetsk: Vyd-vo «Noulidzh».

3. Zakharov, A. I. (1982). Psikhoterapiia nevrozov u detei i podrostkov [Psychotherapy of neuroses of children and adolescents]. Leningrad: Meditsina.

44. Kon, I. S. (2004). Detstvo kak sotsialnyi fenomen [Childhood as a social phenomenon]. Zhurnal Issledovanii Sotsialnoi Politiki, 2 (2), 151-175.

5. Leshaft, P.F. (1991). Simeine vykhovannia dytyny $i$ yoho znachennia [Family education of the child and its significance]. Moscow

6. Natsionalna prohrama vykhovannia ditei ta uchnivskoi molodi $\mathrm{v}$ Ukraini [National program for education of children and youth in Ukraine]. (2004). Svit Vykhovannia, № 4 (5), 6-31.

7. Pavelkiv, R. V. (2008). Dytiacha psykholohiia [Children's Psychology].

8. Ponimanska, T. I. (2004). Doshkilna pedahohika [Preschool pedagogy]. Kyiv: «Akadem-vydav».

9. Rohalska, I. P. (2009). Teoretyko-metodychni zasady sotsializatsii osobystosti u doshkilnomu dytynstvi [Theoretical and methodical principles of socialization of personality of preschoolers]. (Doctoral dissertation, Uman). 